\title{
BEBLABADAN BAHASA BALI DALAM PERSPEKTIF EKOLINGUISTIK
}

\author{
I Gusti Ngurah Adi Rajistha \\ STIBA Mentari Kupang \\ ngurah.adi.rajistha@gmail.com
}

\begin{abstract}
Abstrak
Peneitian ini adalah bagian dari tesis penulis. Tujuan dari penelitian ini adalah untuk menjelaskan (1) kategori gramatikal dari leksikon alam yang digunakan dalam beblabadan, (2) konstruksis sintaksis dari beblabadan yang mengandung leksikon alam, dan (3) tiga dimensi praksis sosial dari beblabadan. Data penelitian ini diperoleh dari buku Basita Paribasa karangan W. Simpen AB. Data yang dikumpulkan adalah berupa frasa dan klausa. Hasil analisis disajikan dengan menggunakan metode formal dan informal. Berdasarkan analisis yang dilakukan, ada tiga temuan dalam analisis ini yaitu (1) kategori gramatikal dari leksikon alam dalam beblabadan adalah verba seperti mabawang (berlaku sebagai bawang) dan nomina seperti jaka (pohon enau); (2) Konstruksi sintaksis dari beblabadan (metafora) yang mengandung leksikon-leksikon alam tersebut antara lain frasa nomina seperti base wayah (seperti daun sirih tua), frasa verba seperti mabawang putih (seperti bawang putih), dan klausa seperti ental magulung (daun lontar digulung); dan (3) dimensi praksis sosial dari beblabadan (metafora) ditunjukkan oleh pola-pola acuan tertentu.
\end{abstract}

Kata kunci: beblabadan (metafora), kategori gramatikal, konstruksi sintaksis, dimensi praksis sosial

\begin{abstract}
This research is a part of writer's thesis. The aims of this research are to explain (1) grammatical category of nature lexicon used in beblabadan, (2) syntactic construction of beblabadan that consists nature lexicon, and (3) three dimensionality of the social praxis of beblabadan. The data of this research were taken from book entitled Basita Parihasa by $W$. Simpen AB. The data collected are in form of phrases and clauses. The result of the analysis was presented by formal and informal meth$o d$. Based on the analysis that was conducted, there are three findings found: (1) the grammatical categories of nature lexicon in beblabadan are verb like mabawang (acting as onion) and noun like jaka (sugar palm); (2) syntactic constructions of beblabadan (metaphor) that consist of nature lexicon are noun phrase like base wayah (like old betel vine), verb phrase like mabawang putih (acting as onion), and clause like ental magulung (rolled palmyra palm); and (3) three dimensionally of the social praxis of beblabadan (metaphor) is showed by the reference patterns.
\end{abstract}

Keywords: beblabadan (metaphor), grammatical category, syntactic construction, three dimensionality of the social praxis

\section{PENDAHULUAN}

Bahasa Bali merupakan salah satu bahasa daerah yang masih digunakan suku Bali dalam berkomunikasi. Bahasa Bali yang digunakan oleh suku Bali tidak hanya digunakan sebagai sarana dalam berkomunikasi tetapi juga sebagai sarana dalam mengekspresikan perasaan. Metafora atau dalam bahasa Bali dikenal dengan beblabadan merupakan salah satu bentuk penggunaan bahasa Bali dalam mengungkapkan sesuatu secara tidak langsung. Beblabadan (metafora) dalam bahasa Bali ini ternyata menggunakan leksikonleksikon alam yang berhubungan dengan kehidupan suku Bali. Penggunaan leksikon -leksikon alam tersebut tentunya tidak terlepas dari manfaat unsur-unsur alam tersebut untuk kehidupan masyarakat Bali.

Beblabadan (metafora) dapat dikatakan sebagai bentuk karya sastra ba- 
hasa Bali yang berkaitan dengan alam sekitar dimana suku Bali tinggal. Berdasarkan bentuk dari beblabadan (metafora) yang cukup sederhana, beblabadan (metafora) ini dapat dikatakan menyajikan konsep yang ada dalam pikiran masyarakat Bali melalui leksikon-leksikon yang tidak berkaitan. Dalam hal ini, beblabadan (metafora) menyampaikan konsep yang ada dalam pikiran masyarakat Bali secara tidak langsung. Beblabadan (metafora) dapat dikatakan terdiri dari tiga unsur yaitu unsur inti (teks yang diujarkan), makna sebenarnya dari teks yang diujarkan, dan makna kias yang dimaksudkan oleh teks tersebut. Makna kias inilah yang merupakan konsep terhadap sesuatu yang disampaikan masyarakat Bali dengan cara tidak langsung.

Ekolinguistik merupakan ilmu yang mempelajari hubungan timbal balik antara dimensi biologis, sosiologis, dan ideologis dari bahasa (Bundsgaard, 2000: 11). Ketiga dimensi tersebut dikenal dengan istilah dimensi praksis sosial. Dilihat dari sudut pandang ekolinguistik ini, bahasa yang digunakan memiliki latar belakang tiga dimensi praksis sosial tersebut yang selanjutnya menggambarkan hubungan bahasa yang digunakan oleh masyarakat dengan alam, konsep pikiran masyarakat, dan penggunaanya dalam berinteraksi dengan masyarakat. Berdasarkan hal tersebut, kajian ekolinguistik dalam beblabadan (metafora) bahasa Bali merupakan suatu kajian yang mampu mengungkap hubungan antara masyarakat Bali dengan lingkungan melalui beblabadan (metafora) ini.

Penelitian-penelitian ekolinguistik terhadap leksikon-leksikon alam atau ekoleksikal bukan pertama kalinya dilakukan. Banyak penelitian mengenai hal tersebut yang telah dilakukan. Tangkas (2013) melakukan penelitian ekolinguistik yang berjudul Khazanah Verbal Kepadian Komunitas Tutur Bahasa Kodi, Sumba Barat Daya: Kajian Ekolinguistik. Penelitian ini menggunakan teori ekolinguistik dialektikal oleh Bang dan Døør (1993). Rasna dan Binawati (2013) menulis artikel yang berjudul Pengetahuan Tanaman Obat Tradisional untuk Penyakit Anak pada Komunitas Remaja di Bali: Sebuah Kajian Ekolinguistik. Objek penelitian yang digunakan adalah leksikon-leksikon tanaman obat tradisional untuk penyakit anak. Selanjutnya Renjaan (2014) melakukan kajian ekolinguistik dengan judul Pemahaman dan Kebertahanan Ekoleksikal Kelautan Guyub Tutur Bahasa Kei: Kajian Ekolinguistik. Penelitian ini menggunakan teori ekolinguistik Haugen dan teori semantik leksikal oleh Parera. Mahayana (2015) menulis tesis tentang ekolinguistik dengan objek penelitian metafora dalam bahasa Bali. Kajian ekolinguistik yang dilakukan oleh Mahayana (2015) tersebut berjudul Leksikon-Leksikon Flora dan Fauna dalam Metafora Bahasa Bali. Dalam kajian ini Mahayana menggunakan teori ekolinguistik oleh Bang dan Døør. Metafora yang dimaksud oleh 
Mahayana (2015) merupakan sesonggan (pepatah), papindan (pengumpamaan) dan sesenggakan (ibarat). Dalam hal ini, penelitian ekolinguistik dengan menggunakan objek penelitian sastra Bali, khususnya beblabadan (metafora) yang juga mengkaji tentang kategori gramatikal dari leksikon-leksikon alam, konstruksi sintaksis dan dimensi praksis sosial dari beblabadan (metafora) belum dilakukan.

Untuk itu penelitian ini adalah penelitian yang perlu dilakukan untuk mengulas fenomena kebahasaan khususnya beblabadan (metafora) menggunakan teori model dialog ekolinguistik dialektikal. Dengan demikian dimensi praksis sosial dari beblabadan (metafora) tersebut dapat dijelaskan secara terperinci. Penelitian ini berusaha memaparkan konsep yang terdapat dalam beblabadan (metafora) yang berkaitan dengan penggunaan bahasa berdasarkan lingkungan (alam) dimana bahasa itu digunakan melalui suatu konstruksi sintaksis tertentu. Penelitian ini juga merupakan suatu bentuk usaha pelestarian kebudayaan berupa sastra Bali, khususnya dalam bentuk beblabadan (metafora), yang sekarang jarang digunakan dalam berinteraksi antar masyarakat pengguna bahasa Bali. Dengan adanya penelitianpenelitian semacam ini, sastra Bali yang mulai ditinggalkan bahkan dilupakan dapat muncul kembali sebagai salah satu bentuk bahasa kias yang digunakan dalam berinteraksi antar masyarakat Bali.

Data penelitian dikumpulkan dengan menggunakan metode kepustakaan. Buku Basita Parihasa dibaca secara sepintas untuk memperoleh isi dari buku tersebut. Selanjutnya, beblabadan dipilih sebagai data penelitian. Beblabadan kemudian dikategorikan berdasarkan penggunaan leksikon biotik dan abiotik yang dicatat pada kartu data. Data dianalisis menggunakan metode analitika bahasa. Metode analitika bahasa digunakan untuk memperjelas kategori gramatikal dari leksikon-leksikon alam yang terkandung dalam beblabadan (metafora), konstruksi sintaksis dari beblabadan (metafora) dan dimensi praksis sosial beblabadan (metafora). Analisis dilakukan melalui tiga tahap yaitu (1) menentukan leksikonleksikon alam sebagai analysandum yang diikuti dengan analysan; (2) menentukan konstruksi sintaksis sebagai analysandum yang diikuti dengan analysan; dan (3) menentukan beblabadan (metafora) sebagai analysandum yang dilanjutkan dengan analysan. Hasil analisis disajikan dengan menggunakan metode formal dan informal.

\section{KONSEP DAN KERANGKA TEORI KONSEP}

\section{Konsep Leksikon}

Kridalaksana (2008: 142) menjelaskan bahwa leksikon merupakan komponen bahasa yang memuat semua informasi tentang makna dan pemakaian kata dalam bahasa. Lebih lanjut dalam Sugono dalam Kamus Besar Bahasa Indonesia menjelaskan leksikon sebagai kosakata, kamus yang 
sederhana, daftar istilah dalam suatu bidang disusun menurut abjad dan dilengkapi dengan keterangannya, komponen bahasa yang memuat semua informasi tentang makna dan pemakaian kata dalam bahasa, atau kekayaan kata yg dimiliki suatu bahasa (Sugono, 2011: 805). Berdasarkan definisi-definisi leksikon tersebut, pengertian mengenai leksikon sebagai kosakatalah yang digunakan dalam penelitian ini.

\section{Konsep Beblabadan}

Simpen (2010: 3) menjelaskan bahwa beblabadan, berasal dari kata babad yang berarti nasihat sesungguhnya yang disampaikan sejak dahulu. Babad juga berarti rabas, atau selaput rongga perut kerbau, atau banteng, atau kambing. "Babad" memperoleh sisipan -el- menjadi belabad sama dengan blabad mendapat akhiran -an kemudian suku pertama mengalami pengulangan menjadi beblabadan yang berarti kata yang memiliki makna konotasi, digunakan untuk menyatakan sesuatu dan mempunyai sajak.

\section{Kategori Gramatikal}

Pei dan Gaynor (1954: 85) menjelaskan kategori gramatikal sebagai the classes into which the words of a language are divided according to their formation, nature, or functions (nouns, verbs, adjectives, etc)' yang berarti bahwa kategori gramatikal tersebut merupakan 'kelas kata dari suatu bahasa yang dibagi menurut pembentukannya, sifat, atau fungsinya (nomina, verba, adjektiva, dan lain-lain)'.

\section{KONSTRUKSI SINTAKSIS}

Silvia dan Claudia (2008: 88) dalam Key Terms in Syntax and Syntactic Theory menjelaskan konstruksi atau konstruksi sintaksis sebagai berikut 'an ordered set of units, arranged in a way to build a larger unit, such as a sentence or a phrase' yang berarti bahwa konstruksi sintaksis merupakan 'pengaturan urutan dari unitunit, disusun berdasarkan suatu cara untuk membentuk unit yang lebih besar, seperti kalimat atau frasa'.

\section{Dimensi Praksis Sosial}

Dimensi praksis sosial merupakan dimensi lingkungan bahasa yang meliputi dimensi ideologis, dimensi sosiologis, dan dimensi biologis. Dimensi ideologis merupakan dimensi mengenai sistem mental individu dan kolektif, sistem kognitif, sistem ideologis dan psikis. Dimensi sosiologis mengenai cara kita mengatur hubungan agar mempertahankan keseluruhan individu. Dimensi biologis mengenai keberadaan kita secara biologis yang bersanding dengan spesies lain (Bundsgaard, 2000: 11).

\section{KERANGKA TEORI}

\section{Teori Tata Bahasa}

Teori tata bahasa yang digunakan dalam penelitian ini adalah teori Quirk (1985). Teori tata bahasa yang digunakan adalah teori kelas kata, teori frasa, dan teori 
klausa.

\section{Kelas Kata}

Quirk (1985: 67) membagi kelas kata ke dalam tiga kelas yaitu kelas tertutup (closed class), kelas terbuka (open class), dan kelas tambahan (additional class). Lebih lanjut Quirk menjelaskan kelas-kelas kata tersebut sebagai berikut

1. Kelas tertutup (closed class)

- Preposisi (preposition) seperti of, at, in, without, in spite of

- Pronomina (pronoun) seperti he, they, anybody, one, which

- Penentu (determiner) seperti the, $a$, that, every, some

- Konjungsi (conjuction) seperti and, that, when, although

- Verba bantu (modal verb) seperti can, must, will, could

- Verba utama (primary verb) seperti be, have, do
2. Kelas terbuka (open class)

- Nomina (noun) seperti John, room, answer, play

- Adjektiva (adjective) seperti happy, steady, new, large, round

- Verba penuh (full verb) seperti search, grow, play

- Adverbia (adverb) seperti steadily, completely, really

3. Kelas tambahan (additional class)

- Numeralia (numberals) seperti one, two, three; first, second, third

- Interjeksi (interjections) seperti oh, ah, ugh, phew

\section{Frasa}

Quirk (1985: 62-63) menerangkan ada lima jenis frasa. Jenis-jenis frasa tersebut adalah frasa verba, frasa nomina, frasa adjektiva, frasa adverbia, dan frasa preposisi.

Tabel 1. Frasa Verba

\begin{tabular}{|l|r|l|}
\hline \multirow{4}{*}{ The ship } & \multicolumn{2}{|c|}{ Frasa Verba } \\
\cline { 2 - 3 } & Auxiliary/auxiliaries & \multicolumn{1}{c|}{ Main Verba } \\
\cline { 2 - 3 } & was & sinking \\
\cline { 2 - 3 } & has been & sunk \\
\cline { 2 - 3 } & must have been & sinking \\
\cline { 2 - 3 } & may have been being & sunk \\
\hline
\end{tabular}

(Quirk, 1985: 62)

Tabel 2. Frasa Nomina

\begin{tabular}{|c|c|c|c|c|c|}
\hline & \multicolumn{5}{|c|}{ Frasa Nomina } \\
\hline \multirow{10}{*}{$\begin{array}{l}\text { I remem- } \\
\text { ber }\end{array}$} & \multirow[b]{2}{*}{$\begin{array}{c}\text { Determina- } \\
\text { tive }\end{array}$} & \multirow[b]{2}{*}{ Premodification } & \multirow[b]{2}{*}{ Head } & \multicolumn{2}{|c|}{ Postmodification } \\
\hline & & & & & $\begin{array}{c}\text { Comple- } \\
\text { mentation }\end{array}$ \\
\hline & & & him & & \\
\hline & & & Peter & & \\
\hline & Alice's & & wedding & & \\
\hline & that & & girl & with the red hair & \\
\hline & all those & fine warm & days & in the country last year & \\
\hline & $\mathrm{a}$ & better & story & & than that \\
\hline & the & best & trip & & that I ever had \\
\hline & $\mathrm{a}$ & good & trip & that I once had & \\
\hline
\end{tabular}

(Quirk, 1985: 62) 
RETORIKA: Jurnal Ilmu Bahasa, Vol. 2, No.1 April 2016, 84

Tabel 3. Frasa Adjektiva

\begin{tabular}{|c|r|c|r|c|}
\hline \multirow{4}{*}{$\begin{array}{c}\text { The weath- } \\
\text { er was }\end{array}$} & \multicolumn{4}{|c|}{ Frasa Adjektiva } \\
\cline { 2 - 5 } & Premodification & Head & & \multicolumn{2}{c|}{ Postmodification } \\
\cline { 2 - 5 } & & pleasant & & \\
\cline { 2 - 5 } & too & hot & & to be enjoyble \\
\cline { 2 - 5 } & & cold & & \\
\hline
\end{tabular}

(Quirk, 1985: 63)

Tabel 4. Frasa Adverbia

\begin{tabular}{|c|r|c|c|c|}
\hline & \multicolumn{4}{|c|}{ Frasa Adverbia } \\
\hline \multirow{4}{*}{$\begin{array}{c}\text { I spoke to } \\
\text { him }\end{array}$} & Premodification & Head & \multicolumn{2}{|c|}{ Postmodification } \\
\cline { 2 - 5 } & & qesterday & & \\
\cline { 2 - 5 } & very & severely & indeed & \\
\cline { 2 - 5 } & as & clearly & & as I could \\
\cline { 2 - 5 } & & & & \\
\end{tabular}

(Quirk, 1985: 63)

Tabel 5. Frasa Preposisi

\begin{tabular}{|c|c|c|}
\hline \multirow{4}{*}{ I met her } & \multicolumn{2}{|c|}{ Frasa Preposisi } \\
\cline { 2 - 3 } & Preposition & Prepositional Complement \\
\cline { 2 - 3 } & for & lunch \\
\cline { 2 - 3 } & at & the corner of the street \\
\cline { 2 - 3 } & on & Saturday morning \\
\hline
\end{tabular}

(Quirk, 1985: 63)

\section{Klausa}

Quirk (1985: 720) juga menjelaskan bahwa terdapat lima kategori fungsional dari unsur pokok klausa. Kelima kategori fungsional tersebut antara lain:

1. Subjek (S)

2. Verba (V)

3. Objek $(\mathrm{O})$ :

- Objek langsung $\left(\mathrm{O}_{\mathrm{d}}\right)$
- $\quad$ Objek tak langsung $\left(\mathrm{O}_{\mathrm{i}}\right)$

4. Pelengkap $(\mathrm{C})$ :

- Pelengkap subjek $\left(\mathrm{C}_{\mathrm{s}}\right)$

- Pelengkap objek $\left(\mathrm{C}_{\mathrm{o}}\right)$

5. Adverbia (A)

- Adverbia berhubungan dengan subjek $\left(\mathrm{A}_{\mathrm{s}}\right)$

- Adverbia berhubungan dengan objek $\left(A_{0}\right)$

Tabel 6. Tipe Klausa Utama

\begin{tabular}{|c|c|c|c|c|c|}
\hline Tipe & $\begin{array}{c}\text { S } \\
\text { (Subject) }\end{array}$ & $\begin{array}{c}\mathrm{V} \\
\text { (Verb) }\end{array}$ & $\begin{array}{c}\text { O } \\
\text { (Object) }\end{array}$ & $\begin{array}{c}\mathrm{C} \\
\text { (Complement) }\end{array}$ & $\begin{array}{c}\text { A } \\
\text { (Adverbial) }\end{array}$ \\
\hline SV & The sun & is shining & & & \\
\hline SVO & That lecture & bored & $m e\left(\mathrm{O}_{\mathrm{d}}\right)$ & & \\
\hline SVC & Your dinner & seems & & ready $\left(\mathrm{C}_{\mathrm{s}}\right)$ & \\
\hline SVA & My office & $i s$ & & & in the next building $\left(\mathrm{A}_{\mathrm{s}}\right)$ \\
\hline \multirow{2}{*}{ SVOO } & \multirow{2}{*}{ I } & \multirow{2}{*}{ must send } & $\begin{array}{l}\text { my parents } \\
\left(\mathrm{O}_{\mathrm{d}}\right)\end{array}$ & & \\
\hline & & & \begin{tabular}{|l|} 
an anniver- \\
sary card $\left(\mathrm{O}_{\mathrm{i}}\right)$
\end{tabular} & & \\
\hline SVOC & Most students & have found & her $\left(\mathrm{O}_{\mathrm{d}}\right)$ & $\begin{array}{l}\text { reasonably help- } \\
\text { ful }\left(\mathrm{C}_{\mathrm{o}}\right)\end{array}$ & \\
\hline SVOA & You & can put & the dish $\left(\mathrm{O}_{\mathrm{d}}\right)$ & & \\
\hline
\end{tabular}

(Quirk, 1985: 721) 


\section{Teori Ekolinguistik Dialektikal}

Bang dan Døør (1993: 2) menjelaskan bahwa 'ecolinguistics is the part of critical, applied linguistics concerned with the ways in which language and linguistics are involved in the ecological crisis' yang berarti bahwa 'ekolinguistik merupakan bagian dari kritis, linguistik terapan yang terkait dengan cara-cara dimana bahasa dan ilmu bahasa terlibat dalam krisis ekologis'. Lebih lanjut Bundsgaard (2000: 11) menjelaskan ekolinguistik atau ekolinguistik dialektikal berdasarkan sudut pandang The ELI Research Group, kelompok penelitian lingkungan, bahasa dan ideologi yang dikembangkan oleh Bang dan Døør, merupakan ilmu yang mempelajari hubungan timbal balik antara dimensi biologis, sosiologis, dan ideologis dari bahasa.

\section{Model Dialog (Dialogue Model)}

Kerangka teori dari tiga dimensi praksis sosial dirumuskan dalam dialogue model (model dialog) oleh Bang dan Døør (2000: 58). Berikut ini adalah diagram 1 yang menjelaskan kerangka teori dari tiga dimensi praksis social tersebut.

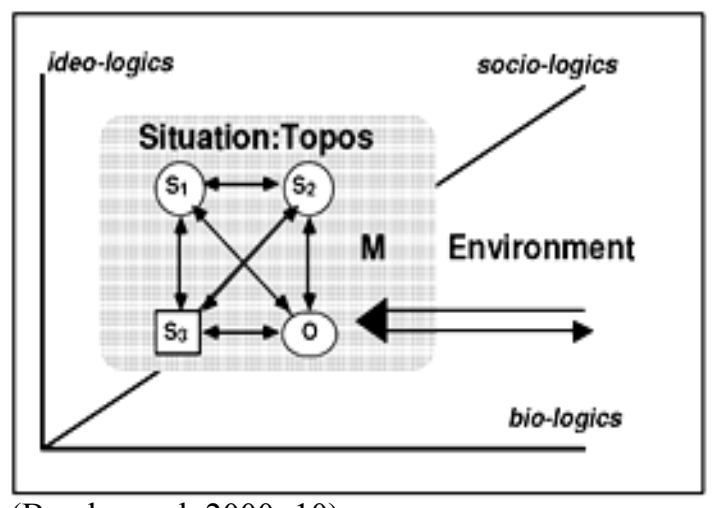

(Bundsgaard, 2000: 10)

Diagram 1. Model Dialog
Model dialog tersebut menjelaskan bahwa empat konstituen yaitu $\mathrm{S}_{1}, \mathrm{~S}_{2}, \mathrm{~S}_{3}$, dan $\mathrm{O}$ terjadi dalam topos (ruang, tempat, dan waktu) dengan latar belakang tiga dimensi praksis sosial yaitu dimensi idiologis, dimensi sosiologis, dan dimensi biologis. Lebih lanjut dijelaskan bahwa $\mathrm{S}_{1}$ merupakan pembuat teks, $\mathrm{S}_{2}$ merupakan konsumen teks, $\mathrm{S}_{3}$ merupakan subjek yang diwujudkan atau tidak berada dalam situasi dialog, dan O merupakan objek yang dirujuk dalam komunikasi (Bundsgaard, 2000: $10)$.

\section{Model Acuan (Triple Model of Refer- ence)}

Dalam menganalisa teks dan menjelaskan hubungan tekstual dari teks tersebut, Bang dan Døør memberikan dasar teori untuk menjelaskan hubungan tekstual yaitu melalui triple model of reference (model acuan). Dalam model dialog dijelaskan ada tiga fungsi tekstual yang memiliki dimensi acuan yang berbeda dan dapat mengacu ke COteks, INteks, atau CONteks. Model acuan tersebut dijelaskan pada tabel 7 berikut ini.

Tabel 7 Model Acuan

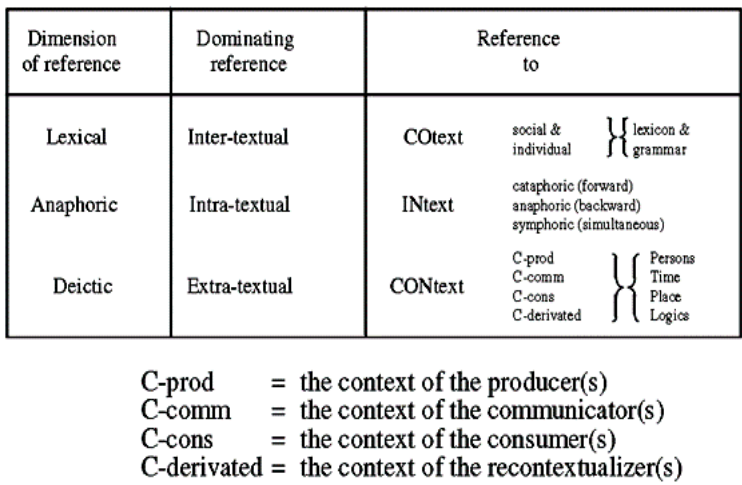

(Bunsdgaard, 2000: 18) 
Berdasarkan tabel di atas, tampak jelas bahwa fungsi inter-tekstual, intratekstual, dan ekstra-tekstual memiliki dimensi acuan dan acuan atau rujukan yang berbeda. Fungsi inter-tekstual memiliki dimensi acuan leksikal dan mengacu pada COtext. Fungsi intra-tekstual memiliki dimensi acuan anaforis dan mengacu pada INtext. Fungsi ekstra-tekstual memiliki dimensi acuan deiksis dan mengacu pada CONtext. Sebagai catatan, ada empat jenis deiksis pada teori ekolinguistik dialektikal yaitu deiksis orang, waktu, tempat, dan logika. Dalam penelitian ini hanya fungsi inter-tekstual lah yang digunakan. Fungsi inter-tekstual ini digunakan dalam menjelaskan leksikal sebagai dimensi acuan yang mengacu pada COteks mengenai pemaknaan individu dan sosial dari beblabadan bahasa Bali. Baik model dialog maupun model acuan digunakan untuk menggambarkan dimensi praksis sosial dari beblabadan bahasa Bali tersebut.

\section{PEMBAHASAN}

Kategori Gramatikal Leksikon-Leksikon Alam dalam Beblabadan

Berdasarkan data beblabadan (metafora) yang digunakan ditemukan bahwa leksikon-leksikon alam yang terkandung dalam beblabadan (metafora) merupakan leksikon-leksikon bernyawa dan tak bernyawa. Leksikon-leksikon bernyawa dapat dikategorikan menjadi leksikon-leksikon flora dan fauna sedangkan leksikon-leksikon tak bernyawa tidak dikategorikan dalam kategori tertentu karena hanya terdapat sedikit data beblabadan (metafora) yang mengandung leksikon-leksikon tak bernyawa. Berdasarkan hasil analisis yang telah dilakukan baik leksikon-leksikon flora, fauna, dan tak bernyawa memiliki kategori gramatikal berupa nomina dan verba. Kategori gramatikal dari leksikon-leksikon tersebut dijelaskan secara rinci pada tabel 8 hingga tabel 10.

Tabel 8. Leksikon-Leksikon Flora

\begin{tabular}{|c|c|c|c|c|c|c|}
\hline \multirow{2}{*}{ No. } & \multicolumn{2}{|c|}{ Leksikon-Leksikon Flora dalam Beblabadan } & \multicolumn{2}{c|}{ Bentuk Gramatikal } & \multicolumn{2}{c|}{ Kategori Gramatikal } \\
\cline { 2 - 7 } & Bahasa Bali & Bahasa Indonesia & Dasar & Turunan & N & V \\
\hline 1. & Base & Daun sirih & + & - & + & - \\
\hline 2. & Biu & Pisang & + & - & + & - \\
\hline 3. & Buah & Pinang & + & - & + & - \\
\hline 4. & Bunga & Bunga & + & - & + & - \\
\hline 5. & Ental & Lontar & + & - & + & - \\
\hline 6. & Gonda & Sayur gonda & + & - & + & - \\
\hline 7. & Jaka & Enau & + & - & + & - \\
\hline 8. & Kelor & Kelor & + & - & + & - \\
\hline 9. & Kladi & Talas & + & - & + & - \\
\hline 10. & Mabawang & - & - & + & - & + \\
\hline 11. & Mabunga & - & - & + & - & + \\
\hline 12. & Makapas & - & - & + & - & + \\
\hline 13. & Makunyit & - & - & + & - & + \\
\hline 14. & Matabia & - & - & + & - & + \\
\hline 15. & Nyuh & Kelapa & + & - & + & - \\
\hline 16. & Pandan & Pandan & + & - & + & - \\
\hline 17. & Sagu & Sagu & + & - & + & - \\
\hline 18. & Tiing & Bambu & + & - & + & - \\
\hline
\end{tabular}


RETORIKA: Jurnal Ilmu Bahasa, Vol. 2, No.1 April 2016, 87

Tabel 9 Leksikon-Leksikon Fauna

\begin{tabular}{|c|c|c|c|c|c|c|}
\hline \multirow{2}{*}{ No. } & \multicolumn{2}{|c|}{ Leksikon-Leksikon Fauna dalam Beblabadan } & \multicolumn{2}{|c|}{ Bentuk Gramatikal } & \multicolumn{2}{|c|}{ Kategori Gramatikal } \\
\hline & Bahasa Bali & Bahasa Indonesia & Dasar & Turunan & $\mathbf{N}$ & $\mathbf{V}$ \\
\hline 1. & Bebek & Bebek & + & - & + & - \\
\hline 2. & Bikul & Tikus & + & - & + & - \\
\hline 3. & Bondol & Burung bondol & + & - & + & - \\
\hline 4. & Bukal & Kelelawar besar & + & - & + & - \\
\hline 5. & Celeng & Babi & + & - & + & - \\
\hline 6. & Cicing & Anjing & + & - & + & - \\
\hline 7. & Goak & Gagak & + & - & + & - \\
\hline 8. & Katak & Katak & + & - & + & - \\
\hline 9. & Kedis & Burung & + & - & + & - \\
\hline 10. & Kukur & Terkukur & + & - & + & - \\
\hline 11. & Lelawah & Kelelawar & - & + & + & - \\
\hline 12. & Lelintah & Lintah & - & + & + & - \\
\hline 13. & Mabuaya & - & - & + & - & + \\
\hline 14. & Maceleng & - & - & + & - & + \\
\hline 15. & Makakul & - & - & + & - & + \\
\hline 16. & Maklipes & - & - & + & - & + \\
\hline 17. & Makutun & - & - & + & - & + \\
\hline 18. & Masiap & - & - & + & - & + \\
\hline 19. & Mauled & - & - & + & - & + \\
\hline 20. & Sampi & Sapi & + & - & + & - \\
\hline 21. & Siap & Ayam & + & - & + & - \\
\hline 22. & Uled & Ulat & + & - & + & - \\
\hline
\end{tabular}

Tabel 10 Leksikon-Leksikon Alam Tak Bernyawa

\begin{tabular}{|c|c|c|c|c|c|c|}
\hline \multirow{2}{*}{ No. } & \multicolumn{2}{|c|}{$\begin{array}{c}\text { Leksikon-Leksikon Alam Tak Bernyawa } \\
\text { dalam Beblabadan }\end{array}$} & \multicolumn{2}{c|}{ Bentuk Gramatikal } & \multicolumn{2}{c|}{ Kategori Gramatikal } \\
\cline { 2 - 7 } & Bahasa Bali & Bahasa Indonesia & Dasar & Turunan & N & V \\
\hline 1. & Matanah & - & - & + & - & + \\
\hline 2. & Tanah & Tanah & + & - & + & - \\
\hline 3. & Yeh & Air & + & - & + & - \\
\hline
\end{tabular}

\section{Konstruksi Sintaksis Beblabadan}

Berdasarkan hasil analisis mengenai konstruksi sintaksis beblabadan (metafora) yang leksikon-leksikon alam, dapat diketahui bahwa beblabadan (metafora) memiliki konstruksi sintaksis berupa frasa nomina, frasa verba, dan klausa. Adapun beblabadan (metafora) yang memiliki konstruksi sintaksis frasa nomina ditunjukkan oleh contoh-contoh berikut ini.

1. Base wayah (Simpen, 2010: 40) sirih tua

'Seperti daun sirih tua'

2. Le-lintah gunung (Simpen, 2010: 41) RED-lintah gunung
'Seperti lintah gunung'

3. Tukad tanpa yeh (Simpen, 2010: 43) sungai PREP air

'Seperti sungai tanpa air'

Pada contoh (1) yaitu beblabadan (metafora) yang berbunyi base wayah (seperti daun sirih tua) dapat diketahui bahwa leksikon flora yang terkandung dalam beblabadan (metafora) tersebut adalah base (daun sirih). Base (daun sirih) memiliki kategori gramatikal berupa nomina. Nomina base (daun sirih) ini bersanding dengan adjektiva wayah (tua) dalam membentuk beblabadan (metafora) ini sehingga 
sangat jelas konstruksi dari beblabadan (metafora) ini berupa frasa nomina yang mengandung unsur inti nomina base (daun sirih).

Leksikon fauna yang terdapat dalam beblabadan (metafora) lelintah gunung (seperti lintah gunung) pada contoh (2) adalah lelintah (lintah). Lelintah (lintah) ini berkategori gramatikal nomina. Leksikon lelintah (lintah) ini bersanding dengan nomina gunung dalam membentuk beblabadan (metafora) tersebut. Berdasarkan pola konstruksi dari beblabadan (metafora) ini, nomina lelintah (lintah) yang diikuti oleh nomina gunung, dapat diketahui bahwa konstruksi sintaksis dari beblabadan (metafora) ini adalah frasa nomina. Inti dari frasa ini adalah nomina lelintah (lintah) sedangkan nomina gunung berperilaku sebagai adjektiva yang memberikan keterangan terhadap nomina inti lelintah (lintah).

Leksikon tak bernyawa yeh (air) digunakan pada contoh (3) yaitu dalam beblabadan (metafora) tukad tanpa yeh (seperti sungai tanpa air). Leksikon tak bernyawa tersebut memiliki kategori gramatikal nomina. Dalam hal ini, beblabadan (metafora) tersebut memiliki konstruksi sintaksis berupa frasa nomina. Nomina inti dari frasa ini, tukad (sungai), hadir sebelum frasa preposisi yang mengandung leksikon tak bernyawa yaitu tanpa yeh (tanpa air).

Konstruksi sintaksis beblabadan (metafora) yang kedua adalah berupa frasa verba. Konstruksi ini menggunakan verba yang dibentuk dengan menambahkan prefiks ma- pada nomina. Berikut ini beberapa contoh beblabadan (metafora) yang memiliki konstruksi sintaksis frasa verba.

4. Ma-bawang putih (Simpen, 2010: 40)

PRE-bawang putih

'Seperti bawang putih'

5. Ma-celeng lua (Simpen, 2010: 40)

PRE-babi betina

'Seperti babi betina'

6. Ma-tanah pasih (Simpen, 2010: 42)

PRE-tanah laut

'Seperti tanah laut'

Beblabadan (metafora) mabawang putih (seperti bawang putih) pada contoh (4) menunjukkan penggunaan verba yang dibentuk dari nomina. Nomina bawang mengalami proses morfologis yang berupa penambahan prefiks $m a$ - sehingga menjadi verba mabawang (seperti bawang). Verba mabawang (seperti bawang) ini merupakan verba yang hanya digunakan dalam konteks beblabadan (metafora). Pengunaan verba tersebut di luar konteks beblabadan (metafora) tidak berterima. Verba mabawang (seperti bawang) bersanding dengan adjektiva putih dalam membentuk konstruksi sintaksis dari beblabadan (metafora) tersebut. Dalam hal ini, beblabadan (metafora) ini memiliki konstruksi sintaksis berupa frasa verba. Verba mabawang (seperti bawang) merupakan inti dari konstruksi ini sedangkan adjektiva putih merupakan suatu pelengkap.

Contoh (5) menunjukkan penggunaan leksikon fauna yang memiliki kategori 
gramatikal berupa verba. Beblabadan (metafora) maceleng lua (seperti babi betina) mengandung verba maceleng (seperti babi) yang dibentuk dari proses morfologis berupa penambahan prefiks $m a-$ pada nomina celeng (babi) sehingga membentuk verba tersebut. Seperti halnya dengan prefiks $m a$ - pada data sebelumnya, makna prefiks $m a$ - 'berlaku sebagai' yang melekat pada nomina celeng (babi) sehingga menjadi maceleng (seperti babi) hanya berterima pada konteks metafora. Verba maceleng (seperti babi) hadir sebelum adjektiva lua (betina) sehingga dapat dijelaskan bahwa beblabadan (metafora) ini memiliki konstruksi sintaksis berupa frasa verba, yaitu verba maceleng (seperti babi) sebagai inti frasa dan adjektiva lua (betina) sebagai pelengkap yang menerangkan verba tersebut.

Pada contoh (6) beblabadan (metafora) matanah pasih (seperti tanah laut) menunjukkan leksikon tak bernyawa tanah yang telah mengalami proses morfologis menjadi matanah (berlaku sebagai tanah). Dalam hal ini, leksikon tak bernyawa matanah (berlaku sebagai tanah) telah memiliki kategori gramatikal berupa verba. Verba matanah (berlaku sebagai tanah) dibentuk dari nomina tanah yang telah memperoleh prefiks ma-. Verba ini hadir sebelum nomina pasih (laut) sehingga dapat disimpulkan konstruksi sintaksis dari beblabadan (metafora) ini adalah frasa verba.

Selain berupa frasa nomina dan frasa verba, beblabadan (metafora) yang mengandung leksikon-leksikon alam juga memiliki konstruksi sintaksis klausa. Adapun beblabadan (metafora) yang memiliki konstruksi sintaksis klausa adaah sebagai berikut.

7. Ental ma-gulung (Simpen, 2010: 41)

lontar PRE-gulung

'Seperti daun lontar digulung'

8. Goak ma-mata barak (Simpen, 2010: 41)

gagak PRE-mata merah

'Seperti gagak bermata merah'

9. Uled ma-kaput (Simpen, 2010: 43)

ulat PRE-balut

'Seperti ulat terbalut'

Contoh (7) menunjukkan bahwa beblabadan (metafora) ental magulung (seperti daun lontar digulung) mengandung leksikon flora yaitu ental (lontar). Kategori gramatikal dari ental (lontar) ini merupakan nomina. Nomina ental (lontar) bersanding dengan verba magulung (digulung). Berdasarkan konstruksi beblabadan (metafora) dan kategori gramatikal yang membentuk beblabadan (metafora) ini dapat diketahui bahwa beblabadan (metafora) ini berupa klausa pasif. Dalam hal ini, nomina ental (lontar) merupakan subjek yang dikenai tindakan karena adanya verba magulung (digulung) yang mengikuti nomina ental (lontar) tersebut.

Contoh (8) menunjukkan beblabadan (metafora) goak mamata barak (seperti gagak bermata merah) yang mengandung leksikon fauna yaitu goak (gagak). Dapat diketahui bahwa leksikon fauna goak (gagak) memiliki kategori gramatikal 
nomina yang menduduki fungsi subjek. Berdasarkan konstruksi sintaksis beblabadan (metafora) yang berupa klausa, tampak jelas bahwa nomina goak (gagak) bersanding dengan verba mamata (bermata) dan adjektiva barak (merah). Seperti yang telah dijelaskan sebelumnya nomina goak (gagak) menduduki fungsi subjek, verba mamata (bermata) merupakan predikat, dan adjektiva barak (merah) merupakan pelengkap yang melengkapi makna predikat.

Kontruksi sintaksis berupa klausa juga ditunjukkan oleh beblabadan (metafora) pada contoh (9). Beblabadan (metafora) uled makaput (seperti ulat terbalut) menunjukkan bahwa nomina uled (ulat) yang merupakan leksikon fauna hadir sebelum verba makaput (terbalut). Berdasarkan hal tersebut beblabadan (metafora) ini memiliki konstruksi sintaksis berpola SV, dengan demikian beblabadan (metafora) ini merupakan klausa. Nomina uled (ulat) merupakan subjek dari klausa ini sedangkan verba makaput (terbalut) merupakan predikat.

\section{Dimensi Praksis Sosial Beblabadan}

Pembahasan mengenai beblabadan (metafora) melalui sudut pandang ekolinguistik dialektikal khususnya teori model dialog meliputi (1) pemaparan mengenai konstituen model dialog dan (2) dimensi praksis sosial beblabadan (metafora). Konstituen model dialog yang dimaksud adalah mengenai subjek dan objek yang terjadi dalam topos.

Model dialog menunjukkan bahwa ada empat konstituen yang terjadi dalam situasi atau topos dengan dilatarbelakangi oleh tiga dimensi praksis sosial berupa dimensi ideologis, sosiologis, dan biologis. Perlu ditekankan di sini bahwa model dialog menjelaskan mengenai dialog yang mengandung tiga subjek. Subjek-subjek tersebut digambarkan sebagai $\mathrm{S}_{1}, \mathrm{~S}_{2}$, dan $\mathrm{S}_{3}$. $\mathrm{S}_{1}$ merupakan pembuat teks, $\mathrm{S}_{2}$ merupakan konsumen teks, dan $\mathrm{S}_{3}$ merupakan subjek anonim berupa kebudayaan atau perintah sosial. Subjeksubjek tersebut mem-bicarakan $\mathrm{O}$ sebagai idea atau pokok pembicaraan.

Pembahasan mengenai seluruh konstituen model dialog ini, baik subjek ataupun objek, harus berdasarkan atas adanya dialog yang menunjukkan bahwa objek tersebut menjadi topik pembicaraan dari subjek. Dalam hal ini, data beblabadan (metafora) yang hanya berupa frasa dan klausa hanya dapat menunjukkan dua konstituen model dialog secara pasti. Dua konstituen tersebut adalah $\mathrm{S}_{3}$ dan $\mathrm{O}$ sedangkan $\mathrm{S}_{1}$ dan $\mathrm{S}_{2}$ hanya bisa ditentukan melalui dialog. Meskipun demikian $\mathrm{S}_{1}$ dan $\mathrm{S}_{2}$ tidak sepenuhnya tidak bisa ditentukan. Keberadaan $\mathrm{S}_{1}$ dan $\mathrm{S}_{2}$ dapat ditentukan melalui penggunaan atau pemilihan bahasa untuk membentuk konstruksi beblabadan (metafora) bahasa Bali ini. Secara umum, beblabadan (metafora) bahasa Bali menggunakan bahasa Bali madya atau bahasa Bali biasa, bukan bahasa Bali alus 
ataupun bahasa Bali kasar. Berdasarkan pemilihan bahasa tersebut ruang lingkup $S_{1}$ dan $\mathrm{S}_{2}$ dapat dipersempit menjadi masyarakat Bali biasa yang menggunakan bahasa Bali madya untuk berkomunikasi. Selain itu beblabadan (metafora) dapat dikatakan suatu permainan bahasa yang digunakan dalam situasi informal atau santai.

Konstituen $\mathrm{S}_{3}$ dan $\mathrm{O}$ yang merupakan konstituen yang pasti dapat dijelaskan melalui model dialog ini. Kedua konstituen tersebut saling berhubungan satu dengan yang lainnya. Dalam hal ini, beblabadan (metafora) sebagai $\mathrm{O}$ merupakan permainan bahasa yang mengandung maksud tertentu. Beblabadan (metafora) digambarkan sebagai $\mathrm{O}$ berdasarkan tujuan penggunaan beblabadan (metafora) ini dalam suatu dialog. Dengan kata lain, beblabadan (metafora) dipilih karena beblabadan (metafora) ini memiliki makna kias tertentu. Keberadaan $\mathrm{S}_{3}$ sebagai subjek anonim berupa budaya atau perintah sosial jelas mempengaruhi $\mathrm{O}$. dalam hal ini, $\mathrm{S}_{3}$ tersebut merupakan suatu budaya berbahasa yang mengikat penggunanya untuk menentukan makna sesungguhnya yang diacu dan makna kias yang dimaksud berdasarkan kemiripan bunyi kedua makna tersebut.

Konstituen model dialog yang telah dijelaskan di atas merupakan konstituen yang menunjukkan beblabadan (metafora) sebagai pokok pembicaraan. Beblabadan (metafora) pada dasarnya dilatarbelakangi oleh tiga dimensi praksis sosial. Dimensi praksis sosial tersebut dapat diketahui melalui pola-pola acuan tertentu yang membentuk beblabadan (metafora) tersebut. Perhatikan diagram 2.

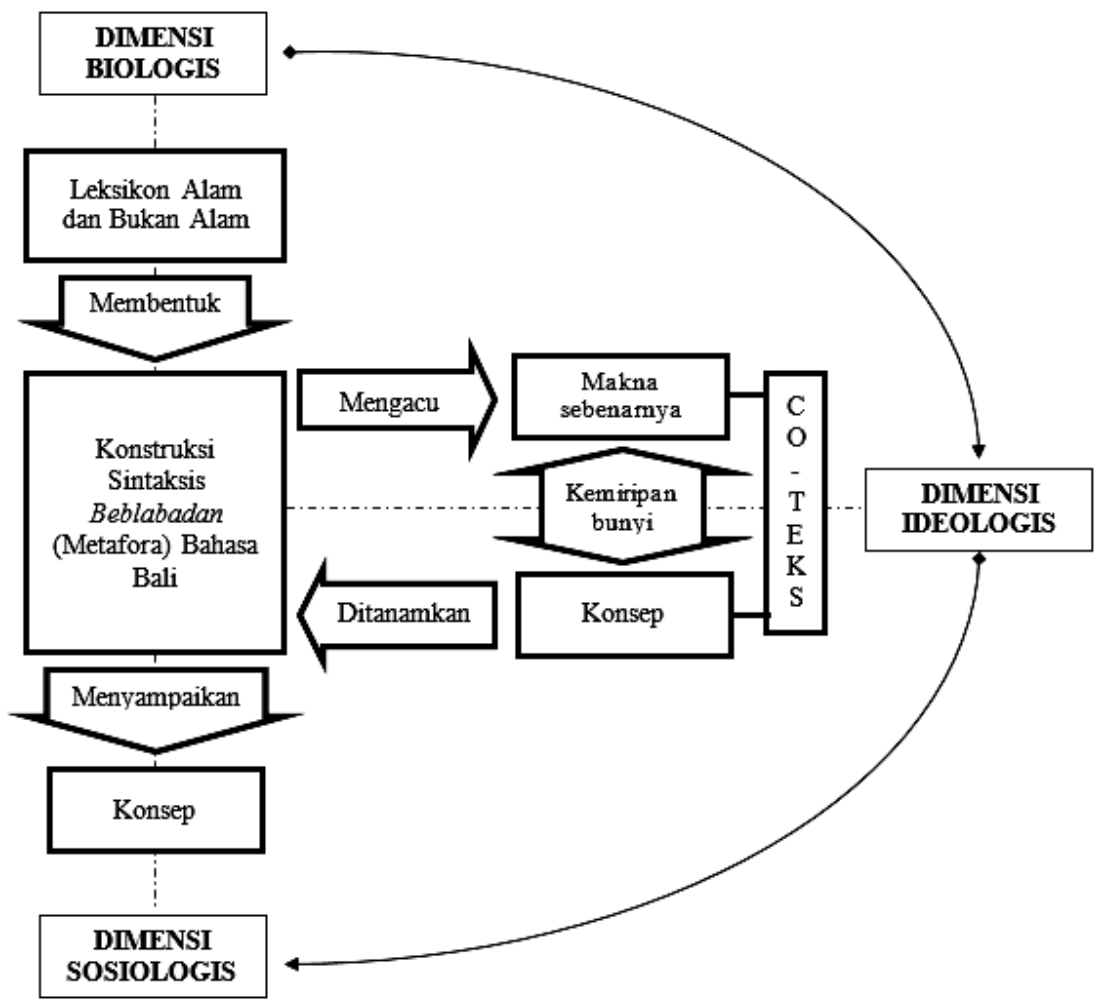

Diagram 2 Dimensi Praksis Sosial Beblabadan 
Untuk memperjelas dimensi praksis sosial dari beblabadan (metafora) bahasa Bali, berikut ini contoh-contoh beblabadan (metafora) yang menunjukkan pola-pola acuan tertentu yang dilatarbelakangi tiga dimensi praksis sosial.

10. Ma-kunyit di alas

(Simpen, 2010: 40)

PRE-kunyit PREP hutan

'Berlaku sebagai kunyit di hutan'

11. Ma-sari-(a)n tanah

(Simpen, 2010: 42)

PRE-sari-SUF tanah

'Seperti sari tanah'

Beblabadan (metafora) makunyit di alas (berlaku sebagai kunyit di hutan) pada contoh (10) memperlihatkan dimensi biologis dari beblabadan (metafora) ini melalui penggunaan leksikon flora berupa verba yaitu verba makunyit (berlaku sebagai kunyit). Verba ini digunakkan tentunya atas dasar keberadaan flora kunyit yang bersentuhan dengan kehidupan masyarakat Bali. Seperti dijelaskan pada analisis sebelumnya bahwa tidak mungkin suatu leksikon digunakan dalam beblabadan (metafora) tanpa adanya flora tersebut atau tanpa adanya pengetahuan mengenai flora tersebut. Keberadaan kunyit yang bermanfaat bagi masyarakat Bali menyebabkan dibentuknya beblabadan (metafora) ini. Konsep katemu (bertemu) pun ditanamkan dalam beblabadan (metafora) ini. Beblabadan (metafora) yang mengacu langsung pada makna sebenarnya yaitu temu (tumbuhan temu) ini yang menjadi dasar pembentukan konsep tersebut. Konsep katemu (bertemu) ini dibentuk berdasarkan kemiripan bunyi antara temu (tumbuhan temu) dan katemu (bertemu). Penanaman konsep dalam beblabadan (metafora) inilah yang mnunjukkan dimensi ideologis dari beblabadan (metafora) tersebut. Dimensi sosiologis dari beblabadan (metafora) ini dapat dilihat dari penggunaan frasa verba makunyit di alas (berlaku sebagai kunyit di hutan) untuk menyatakan konsep katemu (bertemu). Dalam hal ini, frasa verba tersebut menyampaikan konsep yang terkandung di dalamnya secara tidak langsung. Pola acuan yang dibentuk beblabadan (metafora) ini adalah $\mathrm{FV} \rightarrow \mathrm{N} \rightarrow \mathrm{V}$. FV merupakan konstruksi sintaksis beblabadan (metafora) ini yaitu makunyit di alas (berlaku sebagai kunyit di hutan). N merupakan makna sejati beblabadan (metafora) ini yang berkategori gramatikal nomina yaitu temu (tumbuhan temu). V adalah konsep tindakan yang tertanam dalam beblabadan (metafora) yaitu katemu (bertemu).

Beblabadan (metafora) pada contoh (11) menunjukkan penggunaan leksikon tak bernyawa tanah. Leksikon tak bernyawa ini menunjukkan unsur tanah yang selalu berdampingan dan dimanfaatkan oleh masyarakat Bali. Pada contoh ini, beblabadan (metafora) masarin tanah (seperti sari tanah) menunjukkan keberadaan tanah yang diibaratkan memiliki sari. Dalam hal ini, penggunaan leksikon tanah dalam beblabadan (metafora) yang mencerminkan keberadaan unsur tanah merupakan dimensi biologis 
dari beblabadan (metafora). Dimensi ideologis dari beblabadan (metafora) ini tercermin dari konsep yang tertanam di dalamnya. Beblabadan (metafora) ini mengandung konsep ibuk (bingung) yang dibentuk dari makna sesungguhnya dari beblabadan (metafora) masarin tanah (seperti sari tanah) tersebut yaitu buk (debu). Konsep tersebut dibentuk berdasarkan kemiripan bunyi dengan makna sesungguhnya dari beblabadan (metafora) tersebut. Dimensi sosiologis dari beblabadan (metafora) ini dapat diketahui melalui frasa verba masarin tanah (seperti sari tanah) untuk menyatakan konsep ibuk (bingung). Beblabadan (metafora) ini memiliki pola acuan $\mathrm{FV} \rightarrow \mathrm{N} \rightarrow$ Adj. $\mathrm{FV}$ merupakan konstruksi sintaksis beblabadan (metafora) yang berupa frasa verba yaitu masarin tanah (seperti sari tanah). $\mathrm{N}$ merupakan makna sejati dari beblabadan (metafora) yang berkategori gramatikal nomina yaitu buk (debu). Adj. merupakan acuan konsep yang berkategori gramatikal adjektiva ibuk (bingung).

\section{SIMPULAN}

Penelitian mengenai beblabadan (metafora) bahasa Bali yang dikaji dengan menggunakan teori tata bahasa Quirk (1985) dan teori ekolinguistik dialektikal oleh Bang dan Døør (1993) mengasilkan tiga temuan. Adapun temuan-temuan tersebut dapat disimpulkan sebagai berikut.

1. Leksikon-leksikon alam (bernyawa dan tak bernyawa) yang terkandung dalam beblabadan (metafora) memiliki kategori gramatikal berupa nomina dan verba.

2. Konstruksi sintaksis dari beblabadan (metafora) yang mengandung leksikonleksikon alam tersebut antara lain frasa nomina, frasa verba, dan klausa.

3. Dimensi praksis sosial dari beblabadan (metafora) ditunjukkan oleh pola-pola acuan tertentu. Dimensi biologis yang ditunjukkan dari penggunaan leksikon alam dalam konstruksi beblabadan (metafora). Dimensi ideologis ditunjukkan oleh konsep yang dibentuk dari makna sejati dari beblabadan (metafora). Dimensi sosiologis ditunjukkan oleh penyampaian konsep melalui konstruksi beblabadan (metafora).

\section{UCAPAN TERIMA KASIH}

Penulis mengucapkan terima kasih kepada Prof. Dr. Aron Meko Mbete dan Dr. Mirsa Umiyati, S.S., M.Hum atas bimbingan yang telah diberikan selama penelitian ini. Ucapan terima kasih juga penulis sampaikan kepada Dr. Dra. A.A. Rai Sita Laksmi, M.Si, Dr. Ni Wayan Kasni, M.Hum, dan Dr. I Wayan Budiarta, S.S., M.Hum atas masukan dan saran yang sangat bermanfaat bagi penelitian ini. Ucapan terima kasih juga penulis sampaikan kepada Mitra Bestari atas masukan-masukan untuk perbaikan artikel ini. 


\section{DAFTAR PUSTAKA}

AB., W. Simpen. 2010. Basita Parihasa. Denpasar: PT. Upada Sastra.

Bundsgaard, Jeppe dan Sune Steffensen. 2000. "The Dialectics of Ecological Morphology-or the Morphology of Dialectics" dalam: Lindø, Anna Vibeke dan Jeppe Bundsgaard (eds.).

Døør, Jørgen dan Jørgen Chr. Bang. 1993. EcoLinguistics: A Framework. Situs: (www.jcbang.dk/main/ecolinguistics/ Ecoling_AFramework1993.pdf) diakses pada tanggal 22 September 2015.

Granoka, Ida Wayan Oka, dkk. 1996. Tata Bahasa Baku Bahasa Bali. Denpasar: Balai Penelitian Bahasa.

Kaelan, 2002. Filsafat Bahasa. Yogyakarta: Paradigma.

Kaelan. 2012. Metode Penelitian Kualitatif Interdisipliner Bidang Sosial, Budaya, Filsafat, Seni, Agama, dan Humaniora. Yogyakarta: Paradigma.

Kesuma, Tri Mastoyo Jati. 2007. Pengantar (Metode) Penelitian Bahasa. Yogyakarta: Carasvatibooks.

Kridalaksana, Harimurti. 2001. Kamus Linguistik. Jakarta: PT Gramedia.

Kridalaksana, Harimurti. 2008. Kamus Linguistik. Jakarta: Gramedia Pustaka Utama.

Lindø, Anna Vibeke dan Jeppe Bundsgaard. 2000. Dialectical Ecolinguistics Three Essays for the Symposium 30 Years of Language and Ecology in Graz December 2000. Odense: University of Odense.

Luraghi, Silvia dan Claudia Parodi. 2008. Key Terms in Syntax and Syntactic Theory. New York: Continuum.

Mahayana, I Made Astu. 2015. LeksikonLeksikon Flora dan Fauna dalam Metafora Bahasa Bali. Denpasar: Universitas Warmadewa.

Mbete, Aron Meko. 2009. "Refleksi Ringan Tentang Problemantika Keetnikan dan Kebahasaan dalam Perspektif Ekolingistik". Makalah Seminar Nasional Budaya Etnik III, USU Medan, 25 April 2009

Mbete, Aron Meko. 2009. "Selayang Pandang Tentang Ekolinguistik: Perspektif Kelinguistikan Yang Prospektif'. Bahan untuk Berbagi Pengalaman Kelinguistikan dalam Matrikulasi Program Magister Linguistik Program Pasca Sarjana Universitas Udayana, 12 Agustus 2009

Mbete, Aron Meko. 2013. Penuntun Singkat Penulisan Proposal Penelitian.
Denpasar: Penerbit Vidia.

Moleong, Lexy J. 2010. Metodelogi Penelitian Kualitatif. Bandung: PT Remaja Rosdakarya.

Pei, Mario A. dan Frank Gaynor. 1954. A Dictionary of Linguistics. New York: Philosophical Library.

Quirk, Randolph, Sidney Greenbaum, Geofrey Leech, dan Jan Svartvik. 1985. A Comprehensive Grammar of the English Language. New York: Longman.

Rasna, I Wayan dan Ni Wayan S. Binawati. 2013. Pengetahuan Tanaman Obat Tradisional untuk Penyakit Anak pada Komunitas Remaja di Bali: Sebuah Kajian Ekolinguistik. Singaraja: Jurnal Bumi Lestari.

Renjaan, Meiksyana Raynold. 2014. Pemahaman dan Kebertahanan Ekoleksikal Kelautan Guyub Tutur Bahasa Kei. Denpasar: Universitas Udayana.

Subiyanto, Agus. 2013. Ekolinguistik: Model Analisis dan Penerapannya. Semarang: Fakultas Ilmu Budaya Universitas Diponogoro.

Sudaryanto. 1992. Metode Linguistik. Yogyakarta: Gadjah Mada University Press.

Sudaryanto. 1993. Metode dan Aneka Teknik Analisis Bahasa: Pengantar Penelitian Wahana Kebudayaan secara Linguistis. Yogyakarta: Duta Wacana University Press.

Sugono, Dendy. 2008. Kamus Besar Bahasa Indonesia Pusat Bahasa. Jakarta: Pusat Bahasa.

Sugono, Dendy. 2011. Kamus Besar Bahasa Indonesia Pusat Bahasa. Jakarta: PT Gramedia Pustaka Utama.

Tangkas, Putu Reland Dafincy. 2013. Khazanah Verbal Kepadian Komunitas Tutur Bahasa Kodi, Sumba Barat Daya: Kajian Ekolinguistik. Denpasar: Universitas Udayana.

Tinggen, I Nengah. 1988. Aneka Rupa Paribasa Bali. Singaraja: Rhika Dewata.

Umiyati, Mirsa. 2011. Ketahanan Khazanah Lingual Pertanian Guyub Tutur Bahasa Bima dalam Perspektif Ekolinguistik Kritis. Semarang: Universitas Diponogoro. 